\title{
Analisis Soal Biologi Berdasar Dimensi Proses Kognitif Dan Karakteristik Hots (Kesesuaian dengan Perencanaan dan Pelaksanaan Pembelajaran)
}

\author{
Achmad Zanuar Ansori \\ Widyaiswara Balai Diklat Keagamaan Surabaya \\ Email: zanuar_a@yahoo.com
}

\begin{abstract}
Abstrak: Penelitian ini bertujuan untuk mengetahui dimensi proses kognitif soal, soal Higher Order Thinking Skills (HOTS), dan kesulitan yang dihadapi guru dalam menghadirkan soal HOTS pada perangkat soal penilaian harian. Penelitian ini juga berusaha mendeskripsikan kualitas RPP dan keterlaksanaan pembelajaran berbasis HOTS. Penelitian ini termasuk deskriptif kuantitatif. Subjek penelitian adalah guru biologi pada dua Madrasah Aliyah Negeri di Kabupaten Lamongan. Data diperoleh dengan teknik dokumentasi dan angket. Data dianalisis dan disajikan dalam bentuk persentase selanjutnya untuk dideskripsikan. Hasil penelitian menunjukkan penilaian harian masih didominasi soal berdimensi proses kognitif mengingat dan memahami, persentase soal HOTS masih rendah, dan menyusun stimulus merupakan kesulitan utama dalam menyusun soal HOTS. Hasil lainnya adalah secara keseluruhan kualitas RPP dan keterlaksanaan pembelajaran berbasis HOTS terkategori sangat baik. Temuan ini menunjukkan adanya kesenjangan antara perencanaan dan pelaksanaan pembelajaran dengan instrumen penilaian yang digunakan. Hal ini berimplikasi hasil penilaian harian belum bisa dipakai sepenuhnya sebagai indikator keberhasilan peserta didik mencapai tujuan pembelajaran.
\end{abstract}

Kata Kunci: penilaian harian, proses kognitif, soal HOTS, perencanaan dan pelaksanaan pembelajaran

\section{PENDAHULUAN}

Peserta didik di tingkat SMA/MA diharapkan memiliki keterampilan berpikir kritis dan pemecahan masalah sebagaimana tujuan pengembangan Kurikulum 2013. Keterampilan berpikir kritis lebih dibutuhkan dibandingkan waktu sebelumnya (Sendag \& Odabasi, 2009) dan diperlukan di tempat kerja (Barry, 2012). Lamb, Maire, \& Doecke (2017) menyatakan penggunaan teknologi dalam kehidupan seharihari dan tempat kerja juga menuntut keterampilan berpikir kritis. Keterampilan berpikir kritis menjadi keterampilan paling penting dalam era revolusi industri 4.0 (Lee et al., 2018). Berpikir kritis menjadi karakter manusia yang diperlukan untuk mampu bersaing di abad 21 (Partnership for 21st Century Skills, 2014). Di sisi lain Indonesia menduduki rangking 71 dari 79 negara peserta Programme for International Student Assessment (PISA) (OECD, 2019).

Penilaian hasil pembelajaran (assessment of learning) memiliki kedudukan yang sangat penting dan membentuk sebuah segi tiga bersama tujuan dan kegiatan pembelajaran (Ditbin SMA, 2017a; Arikunto, 2013). Penilaian oleh pendidik memainkan peran penting untuk mempraktikkan dan melatih keterampilan tertentu peserta didik. Pada dasarnya, penilaian yang diterapkan dapat mencerminkan dimensi proses kognitif dan keterampilan berpikir tingkat tinggi atau Higher Order Thinking Skills (HOTS). Brookhart (2010) mendefinisikan HOTS sebagai proses transfer, berpikir kritis, dan pemecahan masalah. King, Goodson, \& Rohani (2017) menyatakan HOTS mencakup berpikir kritis, logis, metakognitif, dan kreatif. Penilaian Harian (PH) menjadi satu-satunya jenis penilaian kompetensi pengetahuan yang dilakukan oleh guru di madrasah (Ditjen Pendis. 2018). Butir soal atau item yang dibuat menunjukkan kualitas kemampuan guru dalam menyusun perangkat soal (Jihad \& Haris, 2008).

Distribusi dimensi proses kognitif dan soal HOTS pada perangkat soal yang dikembangkan guru masih menyisakan pertanyaan. Distribusi dimensi proses kognitif pada item cenderung masih belum proporsional. Proses kognitif mengingat, memahami dan menerapkan masih mendominasi (Arti \& Hariyatmi, 2015; Pratiwi \& Hariyatmi, 2015; Utami \& Aryeni, 2018).

Persentase soal HOTS yang disusun guru SMA masih berkisar 21,2\% (Arti \& Hariyatmi, 2015); $1,1 \%$ (Pratiwi \& Hariyatmi, 2015) dan 
kurang dari $6 \%$ pada perangkat soal ujian akhir sekolah (Utami \& Aryeni, 2018). Sementara, soal HOTS pada UN Biologi pada tahun 20142016 mencapai 29,16\% (Guchi, 2017; Putra, 2017). Sudijono (2009) menyatakan faktor internal yang memengaruhi guru dalam menyajikan soal meliputi kemampuan guru dalam menilai, pengalaman menyusun soal, dan kesadaran bahwa menyusun soal merupakan kompetensi yang harus dikuasai.

Perencanaan dan pelaksanaan pembelajaran yang dikembangkan harus mampu membekali peserta didik dengan keterampilan abad 21 ((Ditbin SMA, 2017b) atau pembelajaran berpikir tingkat tinggi (Ditjen Pendis, 2018). Hariyatmi dan Syaifulloh (2016) melaporkan kemampuan guru dalam menyusun Rencana Pelaksanaan Pembelajaran (RPP), melaksanakan pembelajaran, dan melakukan penilaian berturut-turut sebesar $67,15 \%, 76,38 \%$, dan $53,69 \%$ dengan rata-rata penerapan sebesar $65,74 \%$, berkategori baik. Temuan lain adalah kemampuan melakukan penilaian aspek pengetahuan termasuk kurang baik yaitu $49,99 \%$. Heriadon dan Manurung (2016) mengungkap kesesuaian RPP biologi komponen penilaian sebesar 38,89\%, terendah diantara semua komponen. Hasil ini sejalan denga temuan Zendrato (2016) yaitu evaluasi belajar menjadi faktor paling sedikit (60\%) dipertimbangkan guru saat menyusun RPP meski tingkat keterlaksanaan pembelajaran secara keseluruhan mencapai $81 \%$.

Hanisa, Syamwil, \& Susanti (2018) menemukan RPP yang disusun guru sudah sesuai dengan pedoman dengan persentase $85,44 \%$ dan komponen penilaian hasil belajar dengan persentase $76,89 \%$ menjadi terendah, menunjukkan penilaian hasil belajar belum sepenuhnya mengacu pada kompetensi yang ditetapkan dan belum mencakup level HOTS. Ramadiah, Abidinsyah, Royani, dan Husamah (2019) menyimpulkan guru mampu membuat persiapan mengajar terkait aspek HOTS dengan baik meskipun tidak konsisten. Sementara, Dwisaktica (2019) mengungkap guru sudah berusaha memenuhi unsur keterampilan berpikir tingkat tinggi pada RPP. Temuan-temuan ini menunjukkan pengembangan RPP berbasis
HOTS oleh guru masih memerlukan usaha yang lebih.

Terkait pelaksanaan pembelajaran berbasis HOTS, Dwisaktica (2019) menyimpulkan bahwa pembelajaran yang dilakukan guru terlihat diusahakan mengarah pada penumbuhan keterampilan berpikir tingkat tinggi. Ramadiah, et al. (2019) mengungkap aspek HOTS kurang disadari dan sedikit terdeskripsikan dalam pembelajaran. Hal ini menunjukkan pembelajaran berbasis HOTS untuk menumbuhkan keterampilan berpikir tingkat tinggi masih perlu diusahakan lagi.

Penelitian ini merupakan lanjutan dari penelitian sebelumnya (Ansori, 2020). Penelitian lanjutan dengan subjek yang sama dipandang perlu untuk mengetahui kesesuaian antara perangkat soal $\mathrm{PH}$ dengan RPP dan keterlaksanaan pembelajaran berbasis HOTS. Penelitian lanjutan dengan data dan analisis baru yang lebih mendalam serta berusaha mengungkap fenomena agar tidak bersifat parsial. Adapun tujuan dari penelitian ini adalah mendeskripsikan distribusi dimensi proses kognitif soal $\mathrm{PH}$, soal HOTS pada $\mathrm{PH}$, dan mengetahui faktor yang memengaruhi penyajian soal HOTS pada PH. Tujuan lain adalah mendeskripsikan kualitas RPP dan keterlaksanaan pembelajaran berbasis HOTS dikaitkan dengan instrumen $\mathrm{PH}$.

\section{METODE}

Penelitian ini termasuk deskriptif kuantitatif . Subjek penelitian adalah seluruh guru Biologi pada dua Madrasah Aliyah Negeri di Kabupaten Lamongan yang berjumlah masing-masing tiga orang. Objek penelitian adalah soal pilihan ganda pada PH dan RPP pembelajaran yang digunakan selama semester gasal 2019/2020.

Pengumpulan data dilaksanakan dalam dua tahapan. Perangkat soal PH dan jawaban angket tentang kesulitan guru dalam menyusun soal HOTS dilakukan pada tahap pertama. Tahap kedua dilakukan untuk mendapatkan dokumen RPP dan keterlaksanaan pembelajaran berbasis HOTS.

Teknik dokumentasi dipakai untuk mendapatkan perangkat soal PH dan RPP. Angket digunakan untuk memperoleh jawaban tentang kesulitan guru dalam menyusun soal 
HOTS dan keterlaksanaan pembelajaran berbasis HOTS. Lembar identifikasi proses kognitif menurut taksonomi Bloom yang direvisi (Anderson \& Krathwol, 2001) digunakan untuk menentukan dimensi proses kognitif butir soal atau item. Kategorisasi item berbasis HOTS diidentifikasi menggunakan lembar identifikasi soal HOTS (Widana, 2017).

Penilaian terhadap kualitas RPP berbasis HOTS ditelaah menggunakan lembar telaah RPP berbasis HOTS yang terdiri atas 9 komponen, 45 indikator, dan 3 skala penilaian (Sunendar dkk, 2018; Dwisaktica, 2019). Penilaian terhadap keterlaksanaan pembelajaran berbasis HOTS menggunakan angket penilaian diri terhadap keterlaksanaan pembelajaran berbasis HOTS yang terdiri atas 7 komponen, 38 indikator dan 4 skala penilaian (Sunendar dkk, 2018).

Data dimensi proses kognitif item dan kategori item berbasis HOTS diolah dan disajikan dalam bentuk persentase (Fraenkel \& Wallen, 2009). Kualitas RPP berbasis HOTS dihitung dengan rumus berikut.

$$
\text { Nilai }=\frac{\text { Jumlah skor yg diperoleh }}{\text { Skor maksimal }} \times 100
$$

(Sunendar dkk, 2018)

Selanjutnya, penentuan predikat RPP menggunakan kriteria berikut.

Tabel 1. Kriteria Predikat RPP

\begin{tabular}{cc}
\hline Nilai & Predikat \\
\hline $\mathrm{N}>81$ & Baik sekali \\
\hline $71 \leq \mathrm{N} \leq 80$ & Baik \\
\hline $\mathrm{N}<71$ & Cukup \\
\hline
\end{tabular}

Sunendar dkk (2018)

Persentase keterlaksanaan pembelajaran diperoleh dengan rumus seperti berikut.

$$
P K P=\frac{\sum \text { tahap pembelajaran yang dilaksanakan }}{\sum \text { seluruh tahap pembelajaran }} \times 100 \%
$$

(Arifin, 2010)

Tingkat keterlaksanaan pembelajaran ditentukan berdasar Tabel 2 .

Tabel 2. Kategori Keterlaksanaan Pembelajaran

\begin{tabular}{cc}
\hline $\begin{array}{c}\text { Persentase } \\
\text { Keterlaksanaan }\end{array}$ & $\begin{array}{c}\text { Kategori } \\
\text { Keterlaksanaan Pembelajaran }\end{array}$ \\
\hline $75 \%-100 \%$ & Terlaksana sangat baik \\
\hline $50 \%-74 \%$ & Terlaksana baik \\
\hline $25 \%-49 \%$ & Kurang terlaksana \\
\hline $0 \%-24 \%$ & Tidak terlaksana \\
\hline
\end{tabular}

(Ratumanan \& Laurens, 2011)

HASIL DAN PEMBAHASAN
Peneliti mendapatkan 215 butir soal yang berasal dari delapan perangkat soal $\mathrm{PH}$ di Madrasah A dan sepuluh perangkat soal PH dengan 250 item pilihan ganda dari di Madrasah B. Dokumen RPP yang ditelaah berturut-turut sebanyak delapan dan sepuluh set.

\section{Dimensi Proses Kognitif}

Data distribusi dimensi proses kognitif item pada PH tersaji pada Tabel 3.

Tabel 3. Distribusi dimensi proses kognitif item $(\%)$

\begin{tabular}{lcc}
\hline \multicolumn{1}{c}{$\begin{array}{c}\text { Dimensi Proses } \\
\text { Kognitif }\end{array}$} & $\begin{array}{c}\text { Madrasah } \\
\text { A }\end{array}$ & $\begin{array}{c}\text { Madrasah } \\
\text { B }\end{array}$ \\
\hline Mengingat (C1) & 50.36 & 35.36 \\
\hline Memahami (C2) & 42.81 & 56.31 \\
\hline Menerapkan (C3) & 3.42 & 7.78 \\
\hline Menganalisis (C4) & 3.42 & 0.56 \\
\hline Mengevaluasi (C5) & 0.00 & 0.00 \\
\hline Mencipta (C6) & 0.00 & 0.00 \\
\hline
\end{tabular}

Diolah dari Ansori (2020)

Tabel 3 menginformasikan bahwa mengingat menjadi dimensi proses kognitif paling dominan digunakan di Madrasah A yaitu $50,36 \%$. Sebaliknya, dimensi proses kognitif memaham $(56,31 \%)$ menjadi paling dominan digunakan di Madrasah B. Temuan ini sejalan dengan beberapa temuan penelitian sebelumnya (Mustarah, 2013; Iskandar \& Senam, 2015; Utami \& Aryeni, 2018) dan jauh dari proporsi ideal dimensi proses kognitif item di SMA/MA (Guchi, 2017; Putra, 2017). Fenomena ini menunjukkan item yang dikembangkan guru biologi di kedua madrasah sebagian besar menguji kemampuan mengingat dan memahami dengan hafalan sebagai hasil belajar (Anderson \& Krathwohl, 2001) dan berakibat menurunkan rasa ingin tahu peserta didik (Oktavianti, 2017).

Analisis lanjutan menunjukkan persentase dimensi proses kognitif mengingat dan memahami yang bertolak belakang antara Madrasah A dan B. Perbedaan ini kemungkinan disebabkan karena guru tidak menggunakan kisikisi soal. Mardapi (1999) menyatakan bahwa banyak guru membuat butir soal tidak berpedoman pada kisi-kisi. Guru cenderung menggunakan soal yang terdapat pada bukubuku di pasaran. Hasil ini sejalan dengan hasil penelitian Arianti (2015) yaitu terdapat lebih dari $50 \%$ guru tidak memiliki dokumen kisi-kisi soal. 
Susiati (2019) menemukan terdapat $82 \%$ soal yang dibuat guru tidak dilengkapi dengan kisikisi soal. Fakta ini juga diungkap oleh Sopiah, Sidauruk, dan Asi (2019) yaitu seluruh guru langsung membuat item sesuai materi yang dipelajari tanpa membuat kisi-kisi soal dan indikator soal terlebih dahulu. Guru lebih memfokuskan diri pada materi dari pada dimensi proses kognitif yang diujikan pada soal. Hal ini menyebabkan soal yang disusun kurang terarah (Arianti, 2015). Miller, Linn, dan Gronlund (2009) menyatakan efektivitas penilaian bergantung pada deskripsi yang cermat tentang apa yang akan dinilai.

Tabel 3 juga mengungkap persentase yang rendah pada dimensi proses kognitif menganalisis di kedua madrasah. Sementara, peserta didik perlu diperkuat kemampuan analisisnya agar mereka dapat menarik kesimpulan (Muhartati, Isnaeni, \& Ridlo, 2019) dan menjadi seorang pemikir kritis (NCSU, 2014).

\section{Soal HOTS}

Berdasar Gambar 1 terungkap bahwa rerata soal HOTS di Madrasah A hanya 0,75\%. Rerata persentase yang lebih rendah terdapat di Madrasah B yaitu sebesar 0,28\%. Temuan ini mirip dengan Budiman \& Jailani (2014), McNeill, Gosper, \& Xu (2012), Pratiwi \& Hariyatmi (2015), and Arti \& Hariyatmi (2015). Dengan demikian tidak ada perubahan yang signifikan terhadap keberadaaan soal HOTS pada $\mathrm{PH}$ yang dilakukan guru. Di sisi lain jumlah soal HOTS pada UN berkisar antara $10 \%$ to $35 \%$ (Guchi, 2017; Putra 2017).

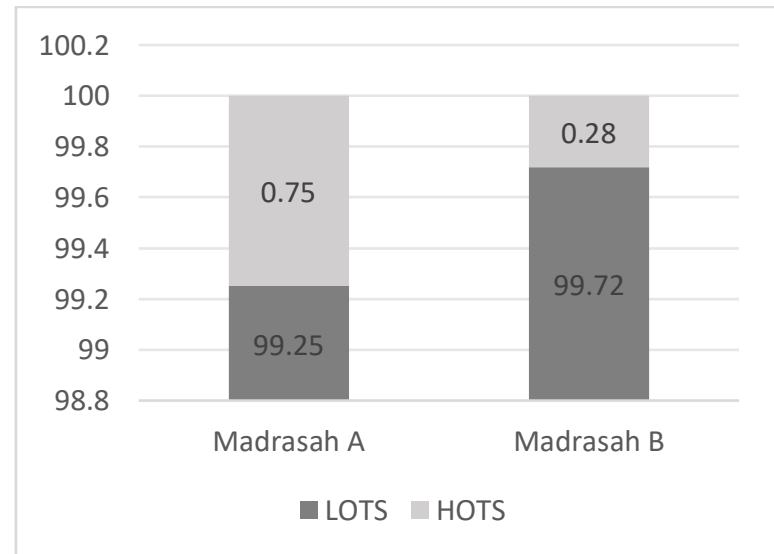

Diolah dari Ansori (2020)
Gambar 1. Rerata persentase soal HOTS pada penilaian harian

Pertanyaan guru merupakan bagian penting dalam pengembangan keterampilan berpikir kritis peserta didik (Hasrudin, 2011) dan guru harus mampu merangsangnya keterampilan tersebut (Sajidan \& Afandi, 2017). Soal HOTS membuat peserta didik memiliki pemahaman lebih terhadap materi pelajaran; mampu menerapkan, menganalisis, dan mengevaluasi; dan lebih baik dalam mengingat pengetahuan Jensen, McDaniel, Woodard, \& Kummer (2014).

\section{Faktor yang memengaruhi penyajian soal HOTS}

Jawaban angket tentang soal HOTS tersaji pada Tabel 4 dan Tabel 5.

Tabel 4. Rangkuman jawaban responden Madrasah A

\begin{tabular}{|c|c|c|c|}
\hline No & Responden 1 & Responden 2 & Responden 3 \\
\hline 1 & Pernah & Pernah & Pernah \\
\hline 2 & $\begin{array}{l}\text { Soal yang } \\
\text { mencirikan } \\
\text { level C4-C6, } \\
\text { penerapan } \\
\text { kehidupan } \\
\text { sehari-hari, dan } \\
\text { menyelesaikan } \\
\text { permasalahan } \\
\text { saat ini }\end{array}$ & $\begin{array}{l}\text { Soal yang } \\
\text { menuntut siswa } \\
\text { menganalisis dan } \\
\text { mengevaluasi, } \\
\text { penerapan dengan } \\
\text { keterampilan } \\
\text { berpikir tingkat } \\
\text { tinggi }\end{array}$ & $\begin{array}{l}\text { Soal HOTS } \\
\text { melibatkan } \\
\text { permasalahan, } \\
\text { menuntut } \\
\text { analisis } \\
\text { permasalahan }\end{array}$ \\
\hline 3 & $\begin{array}{l}\text { Menganalisis } \\
\text { suatu } \\
\text { permasalahan, } \\
\text { menyelesaikan } \\
\text { atau memberi } \\
\text { solusi atau } \\
\text { menyimpulkan }\end{array}$ & $\begin{array}{l}\text { Soal HOTS meng } \\
\text { ukur kemampuan } \\
\text { berpikir tingkat } \\
\text { tinggi, berbasis } \\
\text { permasalahan } \\
\text { kontekstual, } \\
\text { stimulus menarik, } \\
\text { tidak familiar, dan } \\
\text { kekinian }\end{array}$ & $\begin{array}{l}\text { Soal yang tidak } \\
\text { sebatas } \\
\text { pengetahuan } \\
\text { saja }\end{array}$ \\
\hline 4 & Pernah & Pernah & Pernah \\
\hline 5 & Tidak selalu & $\mathrm{Ya}$ & $\begin{array}{l}\text { Ada pada } \\
\text { beberapa nomor }\end{array}$ \\
\hline 6 & $\begin{array}{l}\text { Membuat narasi } \\
\text { dari suatu per- } \\
\text { nyataan dalam } \\
\text { permasalahan, } \\
\text { membuat opsi } \\
\text { jawaban }\end{array}$ & $\begin{array}{l}\text { Membuat konteks } \\
\text { yang nyata dan } \\
\text { mudah dipahami } \\
\text { siswa }\end{array}$ & $\begin{array}{l}\text { Membuat } \\
\text { paparan atau } \\
\text { permasalahan } \\
\text { yang harus } \\
\text { dianalisis siswa }\end{array}$ \\
\hline 7 & $\begin{array}{l}\text { Ya, tapi } \\
\text { disesuaikan } \\
\text { dengan materi }\end{array}$ & $\begin{array}{l}\text { Ya, meskipun } \\
\text { tidak semua }\end{array}$ & $\begin{array}{l}\text { Wajib ada, } \\
\text { untuk melatih } \\
\text { siswa } \\
\text { menghadapi } \\
\text { UTBK/UNBK }\end{array}$ \\
\hline
\end{tabular}

Tabel 5. Rangkuman jawaban responden Madrasah B

\begin{tabular}{|c|c|c|c|}
\hline No & Responden 1 & Responden 2 & Responden 3 \\
\hline 1 & Pernah & Pernah & Pernah \\
\hline
\end{tabular}




\begin{tabular}{|c|c|c|c|}
\hline No & Responden 1 & Responden 2 & Responden 3 \\
\hline 2 & $\begin{array}{l}\text { Soal yang } \\
\text { menuntut siswa } \\
\text { berpikir dengan } \\
\text { tingkatan tinggi }\end{array}$ & $\begin{array}{l}\text { Soal yang membu } \\
\text { tuhkan berpikir } \\
\text { tingkat tinggi, } \\
\text { stimulus sebagai } \\
\text { awalan, level } \\
\text { kognitif C4-C6 }\end{array}$ & $\begin{array}{l}\text { Soal yang } \\
\text { mengarah pada } \\
\text { tingkat C4 }\end{array}$ \\
\hline 3 & $\begin{array}{l}\text { Perbedaannya di } \\
\text { tingkat } \\
\text { taksonomi } \\
\text { Bloom }\end{array}$ & $\begin{array}{l}\text { Soal yang diawali } \\
\text { dengan stimulus, } \\
\text { level kognitif } \\
\text { minimal C4 }\end{array}$ & $\begin{array}{l}\text { Soal HOTS } \\
\text { minimal C4 ke } \\
\text { atas }\end{array}$ \\
\hline 4 & Pernah & Pernah & Pernah \\
\hline 5 & Selalu & Selalu ada & Tidak \\
\hline 6 & $\begin{array}{l}\text { Mengidentifikas } \\
\text { i materi yang } \\
\text { sesuai dengan } \\
\text { taraf berpikir } \\
\text { siswa }\end{array}$ & $\begin{array}{l}\text { Mencari stimulus } \\
\text { yang sesuai } \\
\text { dengan materi, } \\
\text { mensinkronkan } \\
\text { KD yang level } \\
\text { kognitif rendah } \\
\text { menjadi tinggi }\end{array}$ & $\begin{array}{l}\text { Penyusunan } \\
\text { soal HOTS } \\
\text { tidak ada } \\
\text { kesulitan }\end{array}$ \\
\hline 7 & Mewajibkan & $\begin{array}{l}\text { Ya, sangat } \\
\text { dianjurkan }\end{array}$ & Mewajibkan \\
\hline
\end{tabular}

Berdasar data pada Tabel 4 dan Tabel 5 diperoleh informasi bahwa responden di kedua madrasah mengetahui soal HOTS. Hal ini diperkuat dengan jawaban bahwa soal HOTS memiliki tingkatan berpikir $\mathrm{C} 4, \mathrm{C} 5$, dan $\mathrm{C} 6$; menuntut siswa menganalisis dan mengevaluasi; melibatkan permasalahan; dan menuntut siswa berpikir tingkat tinggi (jawaban no. 2). Hal yang membedakan soal HOTS dengan soal bukan HOTS terletak pada penggunaan stimulus, permasalahan yang kontekstual, dan tidak sebatas menggunakan pengetahuan atau mengingat dalam menjawab soal (jawaban no. $3)$.

Seluruh responden menyatakan pernah membuat soal HOTS. Terhadap pertanyaan kelima, terdapat dua kelompok jawaban yang berbeda yaitu mereka tidak selalu dan selalu menghadirkan soal HOTS pada PH. Akan tetapi jawaban ini tidak dapat terkonfirmasi dengan baik karena dalam perangkat soal $\mathrm{PH}$ ditemukan fakta tidak ada soal HOTS pada di kelas X dan XI. Dua kemungkinan untuk menjelaskan fenomena ini adalah mereka pernah membuat soal HOTS, tetapi tidak dipakai dalam PH. Kedua adalah terdapat perbedaan interpretasi terhadap sebuah item antara responden dengan peneliti. Hasil ini sejalan dengan temuan Driana \& Ernawati (2019) yang menyatakan guru memiliki kecenderungan untuk menyatakan item yang mereka susun sebagai HOTS meskipun item tersebut termasuk kategori LOTS.

Lima responden yang menyatakan mengalami kesulitan dalam menyusun soal HOTS. Kesulitan yang mereka hadapi adalah mencari atau menyusun stimulus yang sesuai dengan taraf berpikir siswa, stimulus yang sesuai materi, dan stimulus sesuai konteks permasalahan. Temuan ini sesuai dengan hasil penelitian sebelumnya (Ansori, 2019). FitzPatrick \& Schulz (2015) menyatakan bahwa keberhasilan penerapan HOTS sebagai hasil belajar ditentukan oleh penilaian yang dilakukan guru.

Terhadap pertanyaan ketujuh, semua guru menyatakan pihak pimpinan madrasah mewajibkan adanya soal HOTS pada PH (Ditjen Pendis, 2018). Guru juga menyadari pentingnya soal HOTS bagi peserta didik sebagaimana dinyatakan Sulaiman et al. (2017), tetapi keterampilan guru menjadi penghalang.

\section{RPP Berbasis HOTS}

Tabel 6 menyajikan hasil Telaah RPP Berbasis HOTS di kedua madrasah.

Tabel 6. Telaah RPP Berbasis HOTS (\%)

\begin{tabular}{|c|c|c|c|c|c|}
\hline \multirow{2}{*}{ No } & \multirow{2}{*}{ Komponen } & \multicolumn{2}{|c|}{ Madrasah A } & \multicolumn{2}{|c|}{ Madrasah B } \\
\hline & & Nilai & Kategori & Nilai & Kategori \\
\hline 1 & Identitas RPP & 100 & $\begin{array}{c}\text { Baik } \\
\text { sekali }\end{array}$ & 100 & $\begin{array}{c}\text { Baik } \\
\text { sekali }\end{array}$ \\
\hline 2 & $\begin{array}{l}\text { Komponen } \\
\text { utama RPP }\end{array}$ & 83.33 & $\begin{array}{c}\text { Baik } \\
\text { sekali }\end{array}$ & 83.33 & $\begin{array}{c}\text { Baik } \\
\text { sekali }\end{array}$ \\
\hline 3 & $\begin{array}{l}\text { Rumusan KI, } \\
\text { KD, dan IPK }\end{array}$ & 85,32 & $\begin{array}{c}\text { Baik } \\
\text { sekali }\end{array}$ & 82,94 & $\begin{array}{c}\text { Baik } \\
\text { sekali }\end{array}$ \\
\hline 4 & $\begin{array}{l}\text { Rumusan tujuan } \\
\text { pembelajaran }\end{array}$ & 75,00 & Baik & 50,00 & Baik \\
\hline 5 & $\begin{array}{l}\text { Materi } \\
\text { pembelajaran }\end{array}$ & 78,47 & Baik & 80,56 & $\begin{array}{c}\text { Baik } \\
\text { sekali }\end{array}$ \\
\hline 6 & $\begin{array}{l}\text { Model/Metode } \\
\text { pembelajaran }\end{array}$ & 100 & $\begin{array}{c}\text { Baik } \\
\text { sekali }\end{array}$ & 93.33 & $\begin{array}{c}\text { Baik } \\
\text { sekali }\end{array}$ \\
\hline 7 & $\begin{array}{l}\text { Media dan } \\
\text { sumber } \\
\text { pembelajaran }\end{array}$ & 100 & $\begin{array}{c}\text { Baik } \\
\text { sekali }\end{array}$ & 94,40 & $\begin{array}{l}\text { Baik } \\
\text { sekali }\end{array}$ \\
\hline 8 & $\begin{array}{l}\text { Langkah } \\
\text { kegiatan } \\
\text { pembelajaran }\end{array}$ & 92,74 & $\begin{array}{l}\text { Baik } \\
\text { sekali }\end{array}$ & 87,50 & $\begin{array}{l}\text { Baik } \\
\text { sekali }\end{array}$ \\
\hline 9 & $\begin{array}{l}\text { Penilaian hasil } \\
\text { belajar }\end{array}$ & 50,00 & Cukup & 69,05 & Cukup \\
\hline & Rerata & 83,33 & $\begin{array}{c}\text { Baik } \\
\text { sekali }\end{array}$ & 81,64 & $\begin{array}{c}\text { Baik } \\
\text { sekali }\end{array}$ \\
\hline
\end{tabular}

Tabel 6 mengungkap secara keseluruhan RPP yang dikembangkan dan digunakan dalam pembelajaran di kedua madrasah termasuk dalam ketegori baik sekali dengan nilai rerata di Madrasah A dan B berturut-turut sebesar 83,33 dan 81,64. Kategori ini menunjukkan RPP yang dikembangkan sudah memenuhi kriteria RPP berbasis HOTS, dapat digunakan untuk menunjang pembelajaran berbasis HOTS, dan melatih keterampilan berpikir tingkat tinggi peserta didik. Secara keseluruhan, 
pengembangan RPP memenuhi persyaratan (Kemdikbud, 2016).

Analisis lanjutan menemukan bahwa indikator nomor 9 yaitu IPK menggunakan kata kerja operasional yang mengarah pada proses kognitif menganalisis, mengevaluasi dan/atau mencipta mayoritas tidak ada di RPP buatan guru di kedua madrasah. Sedangkan, indikator nomor 45 yaitu memuat soal HOTS tidak terpenuhi sama sekali di kedua madrasah. Hal ini berakibat pada rendahnya nilai komponen penilaian hasil belajar.

\section{Keterlaksanaan Pembelajaran Berbasis HOTS}

Tabel 7 menunjukkan keterlaksanaan pembelajaran menggunakan RPP berbasis HOTS di kedua madrasah termasuk kategori sangat baik, meskipun persentasenya belum terlalu maksimal. Hal ini berarti pembelajaran Biologi di kedua madrasah mendukung penumbuhan keterampilan berpikir tingkat tinggi.

Tabel 7. Keterlaksanaan Pembelajaran Berbasis HOTS

\begin{tabular}{|c|l|c|c|c|c|}
\hline \multirow{2}{*}{ No } & \multirow{2}{*}{ Komponen } & \multicolumn{2}{|c|}{ Madrasah A } & \multicolumn{2}{c|}{ Madrasah B } \\
\cline { 3 - 6 } & Nilai & Kategori & Nilai & Kategori \\
\hline 1 & $\begin{array}{l}\text { Kegiatan } \\
\text { pendahuluan }\end{array}$ & 95,00 & $\begin{array}{c}\text { Sangat } \\
\text { baik }\end{array}$ & 90,00 & $\begin{array}{c}\text { Sangat } \\
\text { baik }\end{array}$ \\
\hline 2 & $\begin{array}{l}\text { Penguasaan } \\
\text { materi } \\
\text { pembelajaran }\end{array}$ & 87,50 & $\begin{array}{c}\text { Sangat } \\
\text { baik }\end{array}$ & 83.33 & $\begin{array}{c}\text { Sangat } \\
\text { baik }\end{array}$ \\
\hline 3 & $\begin{array}{l}\text { Implementasi } \\
\text { pembelajaran }\end{array}$ & 75,69 & $\begin{array}{c}\text { Sangat } \\
\text { baik }\end{array}$ & 72,92 & Baik \\
\hline 4 & $\begin{array}{l}\text { Pemanfaatan } \\
\text { media dan } \\
\text { sumber } \\
\text { pembelajaran }\end{array}$ & 75,00 & $\begin{array}{c}\text { Sangat } \\
\text { baik }\end{array}$ & 66,67 & Baik \\
\hline 5 & $\begin{array}{l}\text { Interaksi } \\
\text { dengan } \\
\text { peserta didik }\end{array}$ & 75,00 & $\begin{array}{c}\text { Sangat } \\
\text { baik }\end{array}$ & 81,67 & $\begin{array}{c}\text { Sangat } \\
\text { baik }\end{array}$ \\
\hline 6 & $\begin{array}{l}\text { Penggunaan } \\
\text { bahasa dalam } \\
\text { pembelajaran }\end{array}$ & 100 & $\begin{array}{c}\text { Sangat } \\
\text { baik }\end{array}$ & 100 & $\begin{array}{c}\text { Sangat } \\
\text { baik }\end{array}$ \\
\hline 7 & $\begin{array}{l}\text { Kegiatan } \\
\text { penutup }\end{array}$ & 83,33 & $\begin{array}{l}\text { Sangat } \\
\text { baik }\end{array}$ & 64,58 & Baik \\
\hline & $\begin{array}{l}\text { Rerata } \\
\text { baik }\end{array}$ & 81,36 & $\begin{array}{l}\text { Sangat } \\
\text { baik }\end{array}$ \\
\hline
\end{tabular}

Pada kegiatan pendahuluan sebagian besar guru menyatakan telah melaksanakan kegiatan pendahuluan sesuai dengan deskripsi. Pada kegiatan inti pembelajaran sub kegiatan implementasi pembelajaran, mayoritas responden di Madrasah A menyatakan melaksanakan kegiatan pembelajaran sesuai indikator dengan discovery learning sebagai model pembelajaran paling sering digunakan Artinya implementasi pembelajaran berbasis HOTS di Madrasah A berlangsung sangat baik, demikian juga di Madrasah B. Implementasai pembelajaran yang berkategori sangat baik sangat mendukung pencapaian keterampilan berpikir tingkat tinggi. Penggunaan discovery learning dapat melatih peserta didik mengonstruksi pengetahuan (Arends, 2009) dan menumbuhkan rasa ingin tahu secara persisten (Mayer dan Alexander. 2017).

Keterkaitan perencanaan, pelaksanaan, dan penilaian pembelajaran

Hasil analisis menunjukkan RPP dan keterlaksanaan pembelajaran termasuk kategori sangat baik untuk mendorong tumbuhnya HOTS. Di sisi lain, hasil analisis butir soal yang digunakan dalam $\mathrm{PH}$ justru sedikit yang berkategori HOTS. Hal ini dapat disebabkan karena penilaian pembelajaran menjadi faktor yang paling sedikit dipertimbangkan saat menyusun RPP (Zendrato, 2016).

Temuan ini berimplikasi bahwa hasil $\mathrm{PH}$ oleh peserta didik belum bisa dipakai sepenuhnya sebagai indikator keberhasilan peserta didik mencapai kompetensi pembelajaran atau Kompetensi Dasar. Fungsi assessment of learning berjalan kurang maksimal.

Pelaksanaan pembelajaran berbasis HOTS yang berkategori sangat baik menjadi kurang dapat dimanfaatkan guru karena soal HOTS yang dipakai dalam PH sedikit. Keberhasilan pelaksanaan pembelajaran berbasis HOTS akan lebih dapat diukur apabila butir soal PH banyak yang HOTS. Penilaian seharusnya dapat berkontribusi dalam peningkatan kualitas proses pembelajaran (assessment for learning) dan belajar peserta didik (Miller, Linn, dan Gronlund, 2009).

\section{KESIMPULAN}

Berdasarkan data, analisis dan pembahasan dapat ditarik kesimpulan yaitu distribusi dimensi proses kognitif item didominasi mengingat dan memahami; persentase soal HOTS tergolong rendah; kesulitan menyusun stimulus soal menjadi faktor yang memengaruhi penyajian soal HOTS; RPP yang disusun dapat dipakai dalam 
pembelajaran berbasis $H O T S$, dan pembelajaran yang dilakukan mendukung pencapaian HOTS.

\section{SARAN}

Data keterlaksanaan pembelajaran pada penelitian ini dengan teknik penilaian diri. Perlu dilakukan penelitian lanjutan dengan melihat langsung proses pembelajaran yang bertujuan untuk mengetahui kesesuaian antara perencanaan dan pelaksanaan pembelajaran dengan mempertimbangkan ketersediaan waktu bagi peneliti.

Pada penelitian ini, dokumen penilaian yang diteliti berupa perangkat soal $\mathrm{PH}$. Penelitian lanjutan perlu dilakukan terhadap prosedur penyusunannya untuk mengetahui kesesuaian antara indikator pencapaian kompetensi, kisi-kisi soal, dan soal yang digunakan dalam $\mathrm{PH}$.

\section{UCAPAN TERIMA KASIH}

Terima kasih kepada Kepala Lembaga Adminstrasi Negara Republik Indonesia, Kepala Badan Litbang dan Diklat Kementerian Agama Republik Indonesia, Kepala Pusat Pendidikan dan Pelatihan Teknis dan Keagamaan, Kepala Balai Diklat Keagamaan Surabaya beserta jajarannya,

Terima kasih kepada reviewer penulisan KTI yaitu Bapak Dr. Asropi, S,IP., M.Si dan Bapak Dr. Widayanto, M.Pd atas segala bimbingannya. Terima kasih pula kepada evaluator sidang tertutup orasi ilmiah Bapak Dr. Muhammad Taufiq, DEA (LAN), Bapak Drs. Aris Windiyanto, M.Si (BKN), dan Bapak Dr. Muhammad Aswad, M.Si (LAN) atas segala masukan.

Terima kasih pula kepada Kepala MAN 1 dan 2 Lamongan atas ijin penelitiannya dan Guru Biologi MAN 1 dan MAN 2 Lamongan untuk semua informasi yang diberikan.

\section{DAFTAR PUSTAKA}

Anderson, L.W. dan Krathwohl, D.R. (2001). A Taxonomy for Learning, Teaching, and Assessing: a revision of Bloom's taxonomy educational objectives. New York: Longman.

Ansori, Z.A. (2019). Pemahaman Guru Biologi Madrasah Aliyah terhadap Soal Higher
Order Thinking Skill. Jurnal Kewidyaiswaraan Lembaga Administrasi Negara, 4(1), 63-70.

Ansori, Z.A. (2020). Analysis of Biology Daily Assessment According to Cognitive Process Dimension and Higher Order Thinking Skills Question. Journal of Biology Education. 9(1), 30-35

Arends, R.I. (2009). Learning to Teach (Edisi Kesembilan), New York: McGraw-Hill.

Arianti, D. (2015). Studi Evaluasi Administrasi Guru Kelas. Manajer Pendidikan, 9(4), 567-578.

Arifin, A. (2010). Metodologi Penelitian Pendidikan Filosofi, Teori \& Aplikasi. Surabaya: Lentera Cendekia.

Arikunto, S. ( 2013). Dasar-dasar Evaluasi Pendidikan. Jakarta: Bumi Aksara.

Arti, E.P.N. \& Hariyatmi. (2015). The Ability of Biology Teacher in Constructing test of HOT (Higher Order Thinking) Question in SMA Negeri 1 Wonosari Klaten. Dalam Seminar Nasional XII Pendidikan Biologi UNS 2015.

Barry, M. (2012). What skills will you need to succed in the future? Tempe, AZ: University of Phoenix.

Brookhart, S.M. (2010). How to assess High order thinking skills in your classroom. Alexandria, Virginia: ASCD.

Budiman, A. \& Jailani. (2014). Pengembangan Instrumen Asesmen Higher Order Thinking Skill (HOTS) pada Mata Pelajaran Natematika SMP Kelas VIII Semester 1. Jurnal Riset Pendidikan Matematika, 1(2), 139-150.

Ditjen Pendis. (2018). Keputusan Direktur Jenderal Pendidikan Islam Nomor 3751 Tahun 2018 tentang Petunjuk Teknis Penilaian Hasil Belajar pada Madrasah Aliyah Jakarta: Ditjen Pendis.

Ditbin SMA. (2017a). Panduan Penilaian oleh Pendidik dan Satuan Pendidikan untuk Sekolah Menengah Atas, Jakarta: Ditjen Pendidikan Dasar dan Menengah.

Ditbin SMA. (2017b). Implementasi Pengembangan Kecakapan Abad 21 dalam Perencanaan Pelaksanaan Pembelajaran (RPP), Jakarta: Ditjen Pendidikan Dasar dan Menengah 
Driana, E. \& Ernawati. (2019).'Teachers' Understanding and Practices in Assessing Higher Order Thinking Skills at Primary Schools". Journal of Teaching \& Education. 1 (2). 110-118.

Dwisaktica, O. (2019). Analisis Pembelajaran Berbasis Higher Order Thinking Skills (HOTS) pada Mata Pelajaran Ekonomi Akuntansi. Skripsi. Yogyakarta. Universitas Sanata Darma.

FitzPatrick, B., dan Schultz, H. (2015). Do curriculum outcomes and assessment activities inscience encourage higher order thinking?. Canadian Journal of Science, Mathematics and Technology Education, 15(2), 136- 154

DOI:10.1080/14926156.2015.1014074

Fraenkel, J. R. dan Wallen, N.E. (2009). How to Design and Evaluate Research in Education (Edisi ke-7). New York: McGraw Hill.

Guchi, P.I. (2017). Analisis Butir Soal Ujian Nasional (UN) Biologi SMA Tahun Pembelajaran 2013/2014, 2014/2015, 2015/2016 Berdasarkan Taksonomi Bloom Revisi. diakses dari http://digilib.unimed.ac.id/27710/.

Hariyatmi dan Syaifullah, A. (2016). Kemampuan Guru Biologi dalam Penerapan Kurikulum 2013 di SMA Negeri Se-Kabupaten Pekalongan, Proceeding Biology Education Conference 13(1), 225-231.

Hanisa, Syamwil, \& Susanti, D. (2018). Implementasi Kurikulum 2013 pada Mata Pelajaran Ekonomi di SMA Negeri di Kota Padang (Tinjauan Rencana Pelaksanaan Pembelajaran). Ecogen. 1(2), 371-378.

Hasruddin. (2011). Analisis Tipe Pertanyaan Siswa pada Penerapan Pembelajaran Kontekstual di Sekolah Menengah Pertama, Jurnal Dinamika Pendidikan, 4(3), 112-119.

Heriadon, T \& Manurung, T. (2016). Analisis Rencana Pelaksanaan Pembelajaran Biologi Kelas XI IPA Berbasis KTSP dan Korelasinya Terhadap Hasil Belajar Siswa di SMA Negeri 1 Parbuluan T.P 2014/2015, Jurnal Pelita Pendidikan, 4(1). 188-195.
Iskandar, D., dan Senam. (20165). "Studi Kemampuan Guru Kimia SMA Lulusan UNY dalam Mengembangkan Soal UAS Berbasis HOTS". Jurnal Inovasi Pendidikan IPA, 1(1), 65-72.

Jensen, J. L., McDaniel, M. A., Woodard, S. M., \& Kummer, T. A. (2014). Teaching to the Test or Testing to Teach: Exams Requiring Higher Order Thinking Skills Encourage Greater Conceptual Understanding, Educ Psychol Rev. 26:307-329. DOI 10.1007/s10648-013-92489

Jihad, A. \& Haris, A. (2008). Evaluasi Pembelajaran. Yogyakarta: Multi Presindo.

Kemdikbud. (2016). Standar Proses. Jakarta: Kemdikbud.

King, F.J. Goodson, L. dan Rohani, F. (2017). Higher order thinking skills: Definition, Teaching Strategies and Assessment. Center for Advancement of Learning and Assessment. diakses dari http://www.cala.fsu.edu/files/higher order_thinking_skills.pdf.

Lamb, S. Maire, Q. dan Doecke, E. (2017). Key Skills for the 21st Century: an evidencebased review. Department of Education, NSW.

Lee, M. Yun, J.J. Pyka, A. Won, D. Kodama, F. Schiuma, G. Park, H. Jeon, J. Park, K. Jung, K. Yan, M.R. Lee, S.Y. dan Zhao, X. (2018). "How to Respond to the Fourth Industrial Revolution, or the Second Information Technology Revolution? Dynamic New Combinations between Technology, Market, and Society through Open Innovation". Journal of Open Innovation, Technology, Market, and Complexity. (4), 2-24.

Mardapi, D. (1999). Estimasi Kesalahan Pengukuran dalam Bidang Pendidikan dan Implikasinya pada Ujian Nasional. Yogyakarta.

Mayer, Richard E. and Alexander, Patricia. A. (eds). (2017). Handbook of Research on Learning and Instruction. Second Edition. New York: Routledge.

McNeill, M., Gosper, M. \& Xu, J. (2012). Assessment Choices to Target Higher Order Learning Outcomes: The Power of 
Academic Empowerment. Research in Learning Technology, 20(3), 283-296. https://doi.org/10.3402/rlt.v20i0. 17595

Miller, M.D, Linn, R.L. dan Gronlund, N.E. (2009). Measurement and Assessment in Teaching. New Jearsy: Pearson Inducation, Inc.

Murtati, D., Isnaeni, W., \& Ridlo, S. (2019). "The Analytical Thinking Skill of Grade XI Students of SMA Negeri 15 Semarang". Journal of Biology Education. 8(1). 106116.

Mustarah, D. (2013). Analisis Soal Ulangan Akhir Semester (UAS) Biologi SMA Kelas $X$ Ditinjau dari Taksonomi Bloom, tersedia di

repository.uinjkt.ac.id/dspace/bitstream/1 23456789/24330/1/Dira\%20Mustarah.pdf

North Carolina State University (NCSU). (2014). Higher-order Skills in Critical and Creative Thinking. diakses dari https://2014.accreditation.ncsu.edu/pdf/ FINAL\% 20QEP\%20DOCUMENT.pdf

OECD. (2019). PISA 2018 Results (Vol. I): What Students Know and Can Do, Paris: PISA, OECD Publishing. diakses dari https://doi.org/10.1787/5f07c754-en.

Oktavianti, F.S., Hindrasti, N.E.K., dan Oktavianti, N.A. (2017). Analisis Soal Ujian Akhir Semester Genap Tahun Ajaran 2016/2017 Berdasarkan Taksonomi Bloom Revisi Kelas X dan XI Mata Pelajaran Biologi di SMA Negeri 3 Tanjungpinang. diakses

dari http://repository.umrah.ac.id/264/1/E\%20J ournal\%20Fani\%20Sonia\%20Oktavianti.p df

Partnership for 21st Century Skills. (2014). P21's Framework for 21st Century Learning. diakses dari http://www. p21. org/abouts/p21-framework.

Pratiwi, I.H. \& Hariyatmi (2015). The Ability of Science Teachers to Make HOT (Higher Order Thinking) Questions and Questions Writing Suitability in SMPN 1 Kragan Rembang. Skripsi. Surakarta: Universitas Muhammadiyah Surakarta.

Putra, H.K. (2017). Profil Soal Ujian Nasional Biologi Tingkat SMA Tahun Ajaran 2014-
2016 Berdasarkan Perspektif Higher Order Thinking Skill (HOTS) (Skripsi). Surakarta: Prodi Biologi Universitas Muhammadiyah Surakarta diakses dari http://eprints.ums.ac.id/ 57001/15/NASKAH\%20 PUBLIKASI143.pdf

Ramadiah, S., Abidinsyah, Royani,M., dan Husamah. (2019). Understanding, Planning, and Implementation of HOTS by Senior High School Biology Teachers in Banjarmasin-Indonesia. International Journal of Instruction. 12(1), 425-440.

Ratumanan, T. G., \& Laurens, T. (2011). Penilaian Hasil Belajar pada Tingkat Satuan Pendidikan (Edisi ke-2). Surabaya: Unesa University Press.

Sajidan \& Afandi, (2017), Pengembangan Model Pembelajaran IPA untuk Memberdayakan Keterampilan Berpikir Tingkat Tinggi, Prosiding Seminar Nasional

Sendag, S. \& Odabasi, F. Effects of an online problem based learning course on content knowledge acquisition and critical thinking skills. Computers \& Education, 53(1),132141. diakses dari https://doi.org/10.1016/j.compedu.2009.0 $1.008,2009$.

Sopiah, A., Sidauruk, S., dan Asi, N.B. (2019). Kualitas Soal Penilaian Akhir Semester (PAS) Buatan Guru Mata Pelajaran Kimia Kelas X IPA SMA Negeri di Kabupaten Seruyan pada Semester Ganjil Tahun Ajaran 2018/2019. Jurnal Ilmiah Kanderang Tingang. 10 (2), 110-126.

Sudijono. A. (2009). Pengantar Evaluasi Pendidikan. Jakarta: PT. Raja Grafindo Persada.

Sulaiman, T. Muniyan, V. Madhvan, D. Hasan, R. dan Rahim. S.S.A. (2017). "Implementation of Higher Order Thinking Skills in Teaching of Science: A Case Study in Malaysia". International Research Journal of Education and Sciences (IRJES). 1 (1). 1-3.

Sunendar, T., Snae, YDI., Sagita, W., Kristiani, N., dan Moroki, ESG. (2018). Pengembangan Fungsi Supervisi Akademik dalam Implementasi Kurikulum 
2013. Jakarta: Ditjen Guru dan Tenaga Kependidikan Kemdikbud.

Susiatin. (2019). Meningkatkan Kemampuan Guru dalam Menyusun Kisi-kisi Soal dengan Metode Pendampingan Pola "OCF". Dinamika Manajemen Pendidikan, 4 (1), 17-24.

Syamwil, H., dan Susanti, D. (2018). Implementasi Kurikulum 2013 pada Mata Pelajaran Ekonomi di SMA Negeri di Kotapadang (Tinjauan Rencana Pelaksanaan Pembelajaran). EcoGen, 1(2), 371-378.

Utami, I.P., dan Aryeni, A. (2018). Analisis Soal Ujian Akhir Semester Mata Pelajaran Biologi Berdasarkan Dimensi Proses Kognitif Taksonomi Anderson". Jurnal Pelita Pendidikan, 6(3), 185- 192.

Widana, W.I. (2017). Penyusunan Soal HOTS. Jakarta: Ditbin SMA

Zendrato, J. (2016). Tingkat Penerapan Rencana Pelaksanaan Pembelajaran dalam Pelaksanaan Pembelajaran di Kelas (Suatu Studi Kasus di SMA Dian Harapan Jakarta). Scholaria, 6(2), 58-73. 